\title{
Effects of Home-Based Care Inter-Professional Education on Students' Outcomes: Mahasarakham University Experiences
}

\author{
Chanuttha Ploylearmsang $^{1}$ [D $\cdot$ Sirinart Tongsiri ${ }^{2} \cdot$ Mathee Pirikannont $^{3} \cdot$ Tharinee Srisaknok $^{1}$
}

Accepted: 5 February 2021 / Published online: 19 February 2021

(c) International Association of Medical Science Educators 2021

\begin{abstract}
This mixed-method research aimed to implement inter-professional education (IPE) as a training process for producing and shaping health and social sciences professionals in three faculties: Medicine, Pharmacy, and Architecture, Urban Design and Creative Arts in Mahasarakham University (MSU), Thailand. Two hundred thirty-two students who registered as second-year students in the 2015 academic year, and third-year students in the 2016 academic year, and fifty patients in six catchment areas of the Faculty of Medicine Hospital, MSU, participated in the study. Six steps of IPE implementation were involved. They were conducted by twenty-four teachers from three faculties, twelve health volunteers in six communities, and five municipality officers. After the IPE activities, students showed significant improvement in their attitudes towards collaborative teamwork. Their performance with regard to IPE home-based care for medical patients improved substantially from year 2 to year $3(73.4 \%$ and $80.9 \%, p=0.001)$. Patients and community representatives were satisfied with students' home visits, and scored them at $>80 \%$. The after-action review among all of the teachers provided information about their views on IPE projects and their recommendations with respect to inter-professional education. IPE schemes can produce beneficial effects for students, teachers, and patients in the community. As a study result of MSU experience, we recommended IPE for higher education institutions.
\end{abstract}

Keywords Inter-professional education $\cdot$ Home-based care $\cdot$ Attitude $\cdot$ Behavior $\cdot$ Implementation

\section{Background and Rationale}

Health education is a formal program to provide information, experience, and learning environments and to develop essential skills and core competencies among students who wish to become health professionals [1]. Such education aims to provide effective programs that have the goal of creating and training health professionals who will be well-trained and highly competent health providers in the future. The COVID-19 global pandemic which has been raging since February 2020 has forced the healthcare sector to adapt to a "new normal." Health professionals need to be people who

Chanuttha Ploylearmsang

chanuttha.p@msu.ac.th

1 Social Pharmacy Research Unit, Faculty of Pharmacy, Mahasarakham University, Mahasarakham 44150, Thailand

2 Faculty of Medicine, Mahasarakham University, Mahasarakham 44000, Thailand

3 Faculty of Architecture Urban design and Creative Arts, Mahasarakham University, Mahasarakham 44150, Thailand are truly collaborative, community focused, aware of the social determinants of health, flexible, competent life-long learners, and able to apply information technology to serve their patients with empathy and compassion. The six trends for the future education of health professionals were initiated in 2020, and IPE is a key strategy for achieving them: [2] (1) better preparation of health professionals who have the ability to work in a team and to collaborate with non-health professionals in order to make contributions that lead to better patient outcomes; (2) longitudinally integrated clinical education that is more patient, community, and chronic disease oriented, and which can therefore produce learners that are much more successfully integrated into team-based clinical practice; (3) education in the social determinants of health and the social and humanistic missions of health professionals that will better position them to make good partnerships with patients, families, and communities; (4) more emphasis on life-long learning and long-term well-being of health professionals; (5) a shift to competency-based, time-variable education of health professionals so as to produce the most competent practitioners possible; and (6) the integration of 
artificial intelligence and information technologies into the continuum of health professionals' education and practices. Health education institutes have to ensure that students in such organizations are properly educated and trained to be effective clinical practitioners and decision makers [3, 4]. In order to do so, educators who work in health-related schools have to understand the philosophy of health education, the effects of instruction on learners, the institutional context, the supportive resources or inputs that should be deployed, and how to design teaching methods that will enhance students' achievements to the maximum extent possible [5].

Experience of inter-professional collaboration as part of a healthcare team for all health professionals is the main objective that is expected [6]. Collaboration between the health service system and the health educational system (demand-supply approach) is needed in order to provide students who plan to enter health-related professions with clinical knowledge and experience, and to show them how to translate theory into practice when providing care to individual patients, families, and communities [5]. It is crucial that efforts are made by both sides to furnish first-rate health education. Inter-professional education (IPE) is defined as a collaborative learning environment delivered by educators in the higher-education sector to learners from two or more health professions and foundational disciplines [7, 8]. IPE is an educational strategy to prepare the future health providers who will serve as a team in the health service system. The study in Brazil (2019) revealed that IPE was obviously understood as a strategic opportunity for stimulating the development of healthcare skills and collaborative practices in the daily life of health-related students [9].

Mahasarakham University (MSU) is a public highereducation institution in Thailand. It focuses on social and community-based engagement with its philosophy of "Public devotion is a virtue of the learned," and its students' identity of "Students with contribution to society and community." In the academic years 2015-2016, three faculties including Medicine, Pharmacy, and Architecture initiated the inter-professional education concept for their teaching into their curricula. The vision of MSU and the philosophy of the three faculties are in harmony with each other, and their core values are geared toward moving forward to serve community/society or communityengaged education. The IPE program at MSU was designed by the three faculties that take part in it, and by municipality officers who were entitled to humanized home-based care. Home-based care is a holistic service including both formal and informal health services that are provided at a patient's home $[9,10]$. In terms of home-based care, inter-professional collaborative teams learn the concept of family medicine with INHOMESSS in order to assess patients' capacity, ability, needs, family relationships, attitude, and behavior, and to observe housing and environments that affect their health and quality of life. INHOMESSS (Immobility, Nutrition, Housing, Other people (genogram), Medication, Physical Examination, Spiritual health,
Health services, and Safety) is a family medicine concept for assessing patients at home.

A group of multidisciplinary learners have to identify and prioritize the problems, and to set solutions or goals that can improve the quality of life of patients and/or their family [8]. The objectives of this study were to implement IPE as a training process for producing and shaping health and social sciences professionals. The main outcomes are inter-professional team attitudes, behaviors, and competencies. It is hoped that it will result in the provision of humanized home-based care that is delivered by a group of students, with a teacher as the facilitator.

\section{Research Methods}

This study was a mixed-method research that was designed to develop and implement IPE among three faculties: Medicine, Pharmacy, and Architecture, Urban Design, and Creative Arts in Mahasarakham University, Thailand.

\section{Implementation of Home-Based Inter-Professional Education}

Before the first semester of the 2015 academic year, a procedure was set by the IPE working group and educators from three faculties. Planned activities and a timeline for IPE were approved by a group of three IPE deans. These are shown in Table 1.

This mixed-method research was based on collaboration among educators who participated in the IPE program at MSU. The main purpose of it was to develop and implement an IPE project, and to investigate students' outcome on IPE and to reflect the IPE process by the use of an after-action review (AAR) among them. Home-based care was used as a learning process for a group of students who were part of the same venture as the educators. Thirty patients in a selected area were visited at their homes by thirty groups of students. Three concepts: family medicine (theme: INHOMESSS), drug use and storage in a house, and Universal Design (UD) for each patient, were employed. Three types of preparation were carried out in three groups by an IPE working group: educators, students, and the community. Educators provided an inter-professional learning atmosphere in which students could form an interprofessional team and indirectly have the opportunity of future teamwork collaboration after they graduated from the university. The planned learning outcomes for IPE students were connected to their attitudes towards teamwork, and their inter-professional team behaviors with respect to home-based care. For patients, the relevant results were their satisfaction with the students' performance. Regarding the community focus, PCU officers and the health volunteers in the community were invited to be involved in the provision of teaching, evaluation, and creative innovation designed by groups of students. 


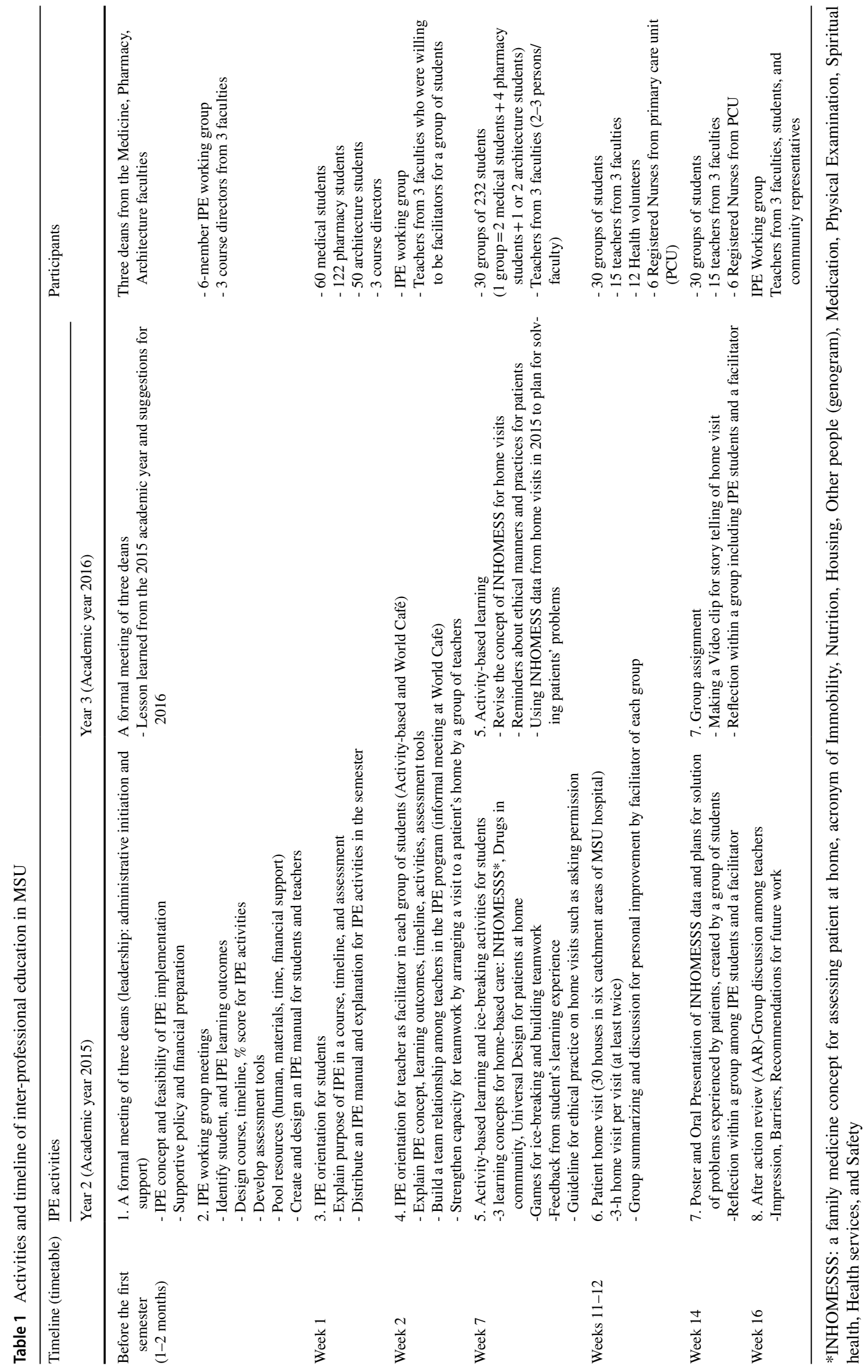


Table 2 IPE courses and contributions among three curricula of three faculties

\begin{tabular}{|c|c|c|c|c|c|}
\hline \multirow[t]{2}{*}{ Faculties } & \multirow[t]{2}{*}{ Number } & \multicolumn{2}{|l|}{ Year 2 (academic year 2015) } & \multicolumn{2}{|l|}{ Year 3 (academic year 2016) } \\
\hline & & Course & $\begin{array}{l}\% \text { score of } \\
\text { IPE* }\end{array}$ & Course & $\begin{array}{l}\% \text { score } \\
\text { of IPE* }\end{array}$ \\
\hline Medicine & 60 & Family medicine 1 & 20 & Family medicine 2 & 20 \\
\hline Pharmacy & 122 & Public Health Pharmacy & 20 & Drug system management 1 & 15 \\
\hline Architecture & 50 & $\begin{array}{l}\text { Introduction to Urban Archi- } \\
\text { tecture \& Environment }\end{array}$ & 15 & Site planning & 15 \\
\hline
\end{tabular}

*From a full score of $100 \%$ in each course, \%score of IPE is the score that the course directors have evaluated for IPE activities
A three-part preparation process was implemented, as follows: (1) a target was set for the relevant academic subjects which had the objective of producing content that would enhance the potential for teachers to be ready to be mentors; it was necessary to determine what competencies the project aimed to instill in students: possess a good attitude, have the capability to work together with people from different professions, know how to work as part of a team, demonstrate a willingness to trust colleagues in different professions, show a capacity for leadership, display enough initiative to plan solutions for patients; (2) activities needed to be organized which would create an understanding among the students of how to behave appropriately when working in the community; and (3) in order to ensure that the students were provided with an environment which was suitable for their studies, cooperation had to be requested from pertinent individuals and organizations: the local municipality, the relevant health service center, community leaders, village health volunteers (VHV), patients and caregivers.

\section{Population and Samples}

The sample or participants in the IPE program consisted of two groups:

(1) Two hundred thirty-two MSU students who registered as second-year students in the 2015 academic year and as third-year students in the 2016 academic year from three faculties: 60 medical students, 122 pharmacy students and 50 architecture students (Field: Urban Design). They enrolled in the courses as shown in Table 2. The students were randomly divided into 30 groups, each group being made up of students from three faculties and 7-8 members per group. One group of students was assigned to make home visits when they were in the second year at least twice, and continued the home visits to the assigned patient in the same house when they were third-year students at least once. Thirty groups of students were facilitated and guided in home visit process and assignment by fifteen teachers from three faculties.

(2) Thirty patients with/without caregiver from 30 houses

Inclusion criteria are as follows: (1) patient who has lived and registered in one of the six catchment areas of the hospital of Faculty of Medicine, MSU, (2) patient who was willing to receive home visits and to be interviewed by a group of students, and (3) patient who was available on the home visit day. Thirty patients from 30 households who met the inclusion criteria were purposively selected by registered nurses from the primary care unit of MSU hospital.

\section{Assessment Methods}

The study results are assessed into two parts: quantitative and qualitative (Table 3 and Table 4).

Table 3 Quantitative results and assessment methods of IPE

\begin{tabular}{ll}
\hline Quantitative results & Assessment methods $^{\mathrm{a}}$ \\
\hline $\begin{array}{l}\text { 1. Student's attitude to IPE and collaborative teamwork from home-based } \\
\text { care (pre-test and post-test) }\end{array}$ & $\begin{array}{l}\text { 10-item with 5-Likert scale }(1=\text { strongly disagree to 5=Strongly agree) } \\
\text { A self-administered questionnaire }{ }^{\mathrm{b}} \text {, developed by the IPE working group, was used to } \\
\text { assess before and after home visit }\end{array}$ \\
$\begin{array}{l}\text { 2. Student's knowledge applicability on INHOMESSS and home health } \\
\text { care to set a solution for patients }\end{array}$ & $\begin{array}{c}\text { dent's presentation day } \\
\text { 8-item with 6-Likert scale assessment form }\end{array}$ \\
$\begin{array}{ll}\text { 3. Student's performance in terms of teamwork during home visit } & \text { Direct observation and assessment during a home visit by } 3 \text { assessors, an educator, a } \\
\text { nurse from PCU, and a health volunteer }\end{array}$
\end{tabular}

${ }^{\text {a }}$ All assessment tools were developed and approved by IPE working group

${ }^{\mathrm{b}}$ They were tested for internal consistency reliability with Cronbach's alpha of $0.68-0.75$ 
Table 4 Qualitative results and assessment methods of IPE

\begin{tabular}{ll}
\hline Qualitative results & Assessment methods \\
\hline 1. Student's expectations and opinions on IPE & Writing a short essay \\
or draw a picture, individual work \\
2. Student's learning from, and reflections on, from IPE & $\begin{array}{c}\text { Drawing a picture or mind map of what they have learned, work as a group of IPE } \\
\text { students }\end{array}$ \\
3. Educator's feedback on IPE process & $\begin{array}{c}\text { After Action Review, group discussion among all educators about impressions on, } \\
\text { barriers faced by, and recommendations about, IPE process }\end{array}$ \\
\hline
\end{tabular}

\section{Data Analysis}

The differences in students' attitudes and collaborative teamwork between year 2 pretest and year 2 posttest, and between year 2 pretest and year 3 posttest, were analyzed using Wilcoxon signed-rank tests. The differences in students' performances in terms of teamwork during home visits that were assessed by teachers between year 2 and year 3 were analyzed using Wilcoxon signed-rank tests. Statistical significance, a two-tailed test, was set at $p<0.05$.

\section{Results}

The results of implementing IPE among three faculties in MSU were reported in 3 parts: general characteristics of IPE students (in Table 5), quantitative effects, and qualitative effects of IPE Implementation.
Table 5 General characteristics of IPE students from 3 faculties $(n=232)$

\begin{tabular}{|c|c|c|c|c|}
\hline \multirow{2}{*}{$\begin{array}{l}\text { General } \\
\text { Characteristics }\end{array}$} & \multicolumn{4}{|c|}{ Number (Percentage) } \\
\hline & $\begin{array}{l}\text { Medical students } \\
(n=60)\end{array}$ & $\begin{array}{l}\text { Pharmacy students } \\
(n=122)\end{array}$ & $\begin{array}{l}\text { Architecture } \\
\text { students } \\
(n=50)\end{array}$ & $\begin{array}{l}\text { Total students } \\
(n=232)\end{array}$ \\
\hline \multicolumn{5}{|l|}{ Gender } \\
\hline - Male & $17(28.3)$ & $19(15.4)$ & $27(54.0)$ & $63(27.2)$ \\
\hline - Female & $43(71.7)$ & $104(83.7)$ & $23(46.0)$ & $169(72.8)$ \\
\hline \multicolumn{5}{|l|}{ Hometown region } \\
\hline - North East (Isan) & $57(95.0)$ & $111(91.0)$ & $45(90.0)$ & $213(91.8)$ \\
\hline - Central & $2(3.3)$ & $5(4.1)$ & $3(6.0)$ & $10(4.3)$ \\
\hline - Bangkok (capital city) & $1(1.7)$ & $3(2.5)$ & $2(4.0)$ & $6(2.6)$ \\
\hline - East & 0 & $3(2.5)$ & 0 & $3(1.3)$ \\
\hline \multicolumn{5}{|c|}{ Activist Volunteer preference } \\
\hline - Not at all & $1(1.7)$ & 0 & $2(4.0)$ & $3(1.3)$ \\
\hline - Some/rare & $6(10.0)$ & $26(21.3)$ & $12(24.0)$ & $44(19.0)$ \\
\hline - Medium & $38(63.3)$ & $74(60.7)$ & $28(56.0)$ & $140(60.3)$ \\
\hline - Much & $11(18.3)$ & $16(13.1)$ & $8(16.0)$ & $35(15.1)$ \\
\hline - Most & $4(6.7)$ & $6(4.9)$ & 0 & $10(4.3)$ \\
\hline \multicolumn{5}{|l|}{ GPAX $^{\mathrm{a}}$ satisfaction } \\
\hline - Unsatisfied & $5(8.3)$ & $10(4.5)$ & $2(4.0)$ & $13(5.6)$ \\
\hline - Somewhat satisfied & $15(25.0)$ & $30(13.5)$ & $16(32.0)$ & $47(20.3)$ \\
\hline - Average satisfied & $31(51.7)$ & $130(58.3)$ & $22(44.0)$ & $124(53.4)$ \\
\hline - Much satisfied & $8(13.3)$ & $48(21.5)$ & $8(16.0)$ & $42(18.1)$ \\
\hline - Most satisfied & $1(1.7)$ & $5(2.2)$ & $2(4.0)$ & $6(2.6)$ \\
\hline \multicolumn{5}{|c|}{$\begin{array}{l}\text { Participation in Student Union or } \\
\text { Student Club }\end{array}$} \\
\hline \multicolumn{5}{|l|}{ - Never participate } \\
\hline - Rarely participate & $3(5.0)$ & $1(0.8)$ & $5(10.0)$ & $9(3.9)$ \\
\hline - Sometimes participate & $9(15.0)$ & $18(14.8)$ & $18(36.0)$ & $45(19.4)$ \\
\hline \multirow[t]{2}{*}{ - Often participate } & 19 (31.7) & $66(54.1)$ & $19(38.0)$ & $104(44.8)$ \\
\hline & $29(48.3)$ & $37(30.3)$ & $8(16.0)$ & 74 (31.9) \\
\hline
\end{tabular}

${ }^{a}$ GPAX is the accumulated (overall) grade-point average that was calculated at the end of the program to summarize the performance of the students during the whole program 
Table 6 Effect of IPE on student's attitude and collaborative teamwork $(n=232)$

\begin{tabular}{|c|c|c|c|}
\hline \multirow{2}{*}{$\begin{array}{l}\text { Items of students' attitude } \\
\text { toward IPE and collaborative teamwork } \\
\text { (Full score }=5 \text { ) }\end{array}$} & \multicolumn{3}{|c|}{ Mean $(\mathrm{SD})(n=232)$} \\
\hline & $\begin{array}{l}\text { Year } 2 \\
\text { Pre-test }\end{array}$ & $\begin{array}{l}\text { Year } 2 \\
\text { Post-test }\end{array}$ & $\begin{array}{l}\text { Year } 3 \\
\text { Post-test } 2^{c}\end{array}$ \\
\hline (1) IPE supports new knowledge exchange & $3.19(0.66)$ & $3.75(0.73)^{* *}$ & $4.43(0.62)^{* *}$ \\
\hline (2) IPE helps me to be a member of patient care team & $3.90(0.69)$ & $4.32(0.62)^{* *}$ & $4.65(0.44)^{* *}$ \\
\hline (3) Collaborative team benefits with respect to quality patient care & $4.16(0.72)$ & $4.53(0.61)^{* *}$ & $4.68(0.49)^{* *}$ \\
\hline (4) IPE facilitates learning atmosphere for inter-professional practice & $4.17(0.66)$ & $4.46(0.61)^{* *}$ & $4.68(0.44)^{* *}$ \\
\hline (5) IPE encourages team relationships and good collaboration & $4.08(0.69)$ & $4.45(0.61)^{* *}$ & $4.68(0.45)^{* *}$ \\
\hline (6) IPE opens new perspectives on other professions & $4.06(0.72)$ & $4.49(0.58)^{* *}$ & $4.71(0.41)^{* *}$ \\
\hline (7) IPE enhances communication skills (intra-team and inter-team) & $3.95(0.68)$ & $4.34(0.62)^{* *}$ & $4.63(0.46)^{* *}$ \\
\hline (8) IPE supports team with the creation of a multi-aspect solution for patients & $3.93(0.69)$ & $4.29(0.63)^{* *}$ & $4.64(0.47)^{* *}$ \\
\hline $\begin{array}{l}\text { (9) Collaborative team with holistic approach can improve patients' and their fam- } \\
\text { ily's quality of life }\end{array}$ & $3.98(0.71)$ & $4.33(0.69)^{* *}$ & $4.59(0.52)^{* *}$ \\
\hline (10) Collaborative team adds value to services for patients & $4.01(0.75)$ & $4.38(0.63)^{* *}$ & $4.53(0.53)^{* *}$ \\
\hline Average score of 10 items $(0-5)$ & $3.94(0.51)$ & $4.33(0.48)^{* *}$ & $4.62(0.37)^{* *}$ \\
\hline Average score of 10 items (\%) & $78.8 \%$ & $86.6 \%$ & $92.4 \%$ \\
\hline
\end{tabular}

${ }^{\mathrm{a}}$ Ten-item self-administered questionnaire with 5 -Likert scale ( $1=$ strongly disagree to $5=$ strongly agree $)$

${ }^{\mathrm{b}}$ Comparing with year 2-pre-test

*statistical significance at $p<0.05 ;{ }^{* *} p<0.01$

\section{General Characteristics of IPE Students}

\section{Quantitative Effects of IPE Implementation}

With the students' response rate at $100 \%$, the three parts of the quantitative results of the study of IPE were (1) the improvement of students' attitudes about collaborative teamwork between year 2-before IPE implementation (pre-test), year 2-after home-based care visit, and year 3-after home visit; (2) students' team performance in terms of home-based care; and (3) patients' and community representatives' satisfaction with students' home visit are shown in Tables 6, 7, and 8. Students' knowledge applicability on INHOMESSS and home health care in each group were scored by educators from three faculties. They ranged between 75.2 and 90.9 (full score of 100) with an average score from 30 groups of 83.2. Peer assessment for students' inter-professional team behavior revealed that in the total of 5 items with 5-level rubric scoring, the average score was 4.96 (ranged 4.89-5.0).
Table 7 Effect of homebased care IPE on students' performance, assessed by teacher $(n=30)$

\begin{tabular}{|c|c|c|c|c|c|}
\hline \multirow{2}{*}{$\begin{array}{l}\text { Teamwork performance during home visit as } \\
\text { assessed by teacher }{ }^{\mathrm{a}} \\
(\text { Full score }=6)\end{array}$} & \multicolumn{2}{|c|}{$\begin{array}{l}\text { Year 2-home visit } \\
(n=30)\end{array}$} & \multicolumn{2}{|c|}{$\begin{array}{l}\text { Year 3-home visit } \\
(n=30)\end{array}$} & \multirow[t]{2}{*}{$p$ - value } \\
\hline & Mean (SD) & $\%$ & Mean (SD) & $\%$ & \\
\hline (1) Working as a team & $4.42(0.85)$ & 73.7 & $4.77(0.61)$ & 79.5 & $0.032 *$ \\
\hline (2) Intra-team communication & $4.58(0.91)$ & 76.3 & $5.04(0.79)$ & 84.0 & $0.008 * *$ \\
\hline (3) Communication skills with patient & $4.42(0.99)$ & 73.7 & $4.88(0.78)$ & 81.4 & $0.012 *$ \\
\hline (4) Inter-professional team for caring for patients & $4.38(1.07)$ & 73.1 & $4.94(0.85)$ & 82.4 & $0.006 * *$ \\
\hline (5) Humanized care and sympathy & $4.60(0.93)$ & 76.6 & $5.00(0.82)$ & 83.3 & $0.010^{*}$ \\
\hline (6) Setting patient care goals & $4.17(0.94)$ & 69.6 & $4.56(0.89)$ & 76.0 & $0.028^{*}$ \\
\hline (7) Critical/problem solving skills & $4.10(0.96)$ & 68.3 & $4.60(0.75)$ & 76.6 & $0.006^{* *}$ \\
\hline (8) Overview of team management & $4.56(0.78)$ & 76.0 & $5.04(0.66)$ & 84.0 & $0.002 * *$ \\
\hline Average score of 8 items $(0-6)$ & $4.40(0.79)$ & 73.4 & $4.85(0.60)$ & 80.9 & $0.001 * *$ \\
\hline
\end{tabular}

${ }^{a}$ Eight-item evaluation form assessed by teachers with 6 -Likert scale $(0=$ unable to perform, $5=$ excellent $)$

${ }^{\mathrm{b}}$ Comparing between year 2-home visit and year-3 home visit by using Wilcoxon signed-rank test

*statistical significance at $p<0.05 ;{ }^{* *} p<0.01$ 
Table 8 Effect of home-based care IPE on patients' and health volunteers' satisfaction

\begin{tabular}{|c|c|c|c|c|}
\hline \multirow{3}{*}{$\begin{array}{l}\text { Overall satisfaction on student's home visit } \\
\text { from year } 2 \text { to year } 3 \\
(\text { Full score }=5 \text { ) }\end{array}$} & \multirow{2}{*}{\multicolumn{2}{|c|}{$\frac{\text { By patient }}{(n=30)}$}} & \multirow{2}{*}{\multicolumn{2}{|c|}{$\frac{\text { By health volunteer }}{(n=12)}$}} \\
\hline & & & & \\
\hline & Mean (SD) & $\%$ & Mean (SD) & $\%$ \\
\hline 1) Students have good manners with regard to talking and asking for information & $4.45(0.51)$ & 89 & $4.21(0.54)$ & 84.2 \\
\hline 2) Students dress appropriately & $4.35(0.59)$ & 87 & $4.26(0.56)$ & 85.3 \\
\hline 3) Students show respect towards patients families, and older people & $4.50(0.51)$ & 90 & $4.37(0.68)$ & 87.4 \\
\hline 4) Students can help each other work well in a them, without any annoyance & $4.35(0.89)$ & 87 & $4.37(0.68)$ & 87.4 \\
\hline 5) Students understand and show compassion to patients and their families & $4.45(0.60)$ & 89 & $4.26(0.56)$ & 85.3 \\
\hline 6) Students can provide humanized care with love & $4.40(0.50)$ & 88 & $4.32(0.58)$ & 86.3 \\
\hline $\begin{array}{l}\text { 7) Students can share ideas or explain useful information on how to take care of } \\
\text { patients' health problems }\end{array}$ & $4.10(0.72)$ & 82 & $4.42(0.61)$ & 88.4 \\
\hline $\begin{array}{l}\text { 8) Students listen to patients' opinions and let patients and family members participate } \\
\text { in solving their own problems }\end{array}$ & $4.15(0.81)$ & 83 & $4.21(0.71)$ & 84.2 \\
\hline 9) Students are able to plan solutions for patients' problems & $4.25(0.64)$ & 85 & $4.53(0.61)$ & 90.5 \\
\hline 10) What level of satisfaction do you have with this student's home visit? & $4.50(0.51)$ & 90 & $4.58(0.51)$ & 91.6 \\
\hline Average score of 10 items (full score $=5$ ) & $4.35(0.46)$ & 87 & $4.35(0.47)$ & 87 \\
\hline
\end{tabular}

${ }^{\text {a }}$ Ten-item interview questionnaire with 5 -Likert scale $(1=$ the least satisfied to $5=$ the most satisfied $)$

\section{Qualitative Effects of IPE Implementation}

An AAR group discussion among 24 teachers of three faculties, including learners, and community representatives was done after the implantation of the IPE project. Three are.

\begin{tabular}{|c|}
\hline Issue \\
\hline
\end{tabular}

Content

- Ice-breaking activities were a beneficial strategy for team building among students and setting a plan. These activities made students from different faculties blend into a group

- Students' feedback was that they learned about each other, and gained friendships with students from other faculties. They were impressed with the welcome that was displayed by patients, and were willing to collaborate in their home visits

- Students' feedback was that they learnt how to collaborate with students from different faculties who had different life patterns

- Brief lecture about principle and concept of INHOMESSS, Universal Design, and drugs in the community were important for students' understanding of Home-based care and reasons to make a home visit

\begin{tabular}{ll}
\hline Issue & Content \\
\hline - It was a very good way for \\
teachers from different faculties \\
to spend time together and share \\
experiences. IPE made them \\
focus and participate in the same \\
thing and be on the same page. \\
- One teacher/facilitator had \\
to take care of more than one \\
house or one group of students. \\
Thus, the level of responsibil- \\
ity may affect their ability to \\
directly observe and accurately \\
score students' performance, \\
especially where students' \\
individual improvement needs to \\
be assessed. \\
- There was no map of patients' \\
houses. Students could not know \\
the way to access a patient's \\
house. They had to wait for a \\
health volunteer in the commu- \\
nity to show them the way. The \\
numbers of health volunteers \\
were limited in this community. \\
- Students in some groups were \\
not prompt/well-prepared for \\
planning their home-based care. \\
They needed extra time for \\
preparation, especially before \\
making a home visit. \\
- Teachers/facilitators were not \\
standardized with respect to \\
rating performance that affected \\
the scoring and grading of \\
students \\
\end{tabular}




\begin{tabular}{ll}
\hline Issue & Content \\
\hline - Use of paper-based assessment \\
that affected resource use and \\
data gathering \\
- Local authorities, such as the \\
municipality, were informed \\
about home visits but they were \\
not involved much \\
- Find more facilitators to cover \\
$1: 1$ teacher: patient's house \\
- Teacher preparation about IPE \\
objective and assessment tools \\
- Students have to be well \\
prepared in order to safeguard \\
patients' confidentially, and \\
ensure that their manner and \\
dress is appropriate for home \\
visits. They must also plan \\
thoroughly for such visits.
\end{tabular}

- Area preparation, good collaboration with municipality officers for preparing patients' houses and map which explains how to access patients' houses.

- Community participation in student's presentation about innovations that are designed to improve patients' quality of life

\section{Discussion}

In the results of a total 232 second-year students from 3 faculties who participated in the IPE activities, it showed that the mean score of students' attitudes towards team learning had increased significantly, from $3.94 \pm 0.51$ to $4.33 \pm 0.48$ (full score $=5$ ), $p<0.001$. Performance with respect to teamwork, when applied to home-based care, was assessed by lecturers who were involved in the project, registered nurses from PCU, and community representatives (health volunteers or municipality officers). The percentage scores that they awarded were 65.5-76.7, 69.5-83.3, and 79.3-88.2, respectively. Patients and caregivers granted scores based on their satisfaction with students' work and performance more than $80 \%$ (expected score) in all items. The highlights of this multidisciplinary program or IPE in Mahasarakham University were that students in health-related and nonhealth-related disciplines blended their different ideas in order to provide a holistic care regime for patients who received care in their homes. This strategy aided them in their attempts to gain knowledge across the broad area of health sciences and to see new perspectives, especially those with social and environmental dimensions. These findings were similar to those of a study in the UK [11] that assessed the effectiveness of IPE in terms of a total of 113 students in their third academic year of higher education courses that people from two different professions participated in: medical students, nursing students, and nursing certificate students, at the University of Manchester. It showed that involvement in an IPE program caused students to learn more, gain increased confidence, understand other professional roles to a greater extent, and be more likely to want to further develop themselves. A study in Singapore (2015) [12] also proved the effect of IPE on 352 learners from 2 different professions who studied together: first-year doctors and nurses. IPE learning outcomes among the students were (1) increased proficiency in teamwork and collaboration, (2) greater knowledge of other professions and understanding of their own professions, and (3) superior understanding of the roles and responsibilities of other professions. A Japanese study in 2019 [13] that used team-based IPE for 42 students of five health-related schools found that multidisciplinary learning made learners ready for multidisciplinary work. There were several IPE studies that showed the beneficial experiences with regard to medical and nursing students [11-15]. The limitation of this study was there was no control group to compare the differences of educational outcomes or the effect of IPE. However, the main goal of this study was to investigate the improvement in learners' outcomes within study year (pre-post) and from study year 2 to study year 3 . We recommend that IPE should be performed continuously in terms of the education of health professionals at both pre-clinical levels (years 1-3), and clinical levels (years 4-6). Moreover, judging by the evidence that IPE benefits all stakeholders, this study could definitely be the foundation for developing other IPE experiences in alternative other settings.

Funding This educational research was financially supported by the Medical Research Network of the Consortium of Thai Medical Schools (MedResNet), Thailand.

\section{Declarations}

Ethical Approval This study was approved as the exempt research by the Ethical Committee of Mahasarakham University, Thailand, in 2015.

Informed Consent Students were provided the research information in oral consent process, and patients were asked for the voluntary agreement to participate in the research.

Conflict of Interest The authors declare that they have no conflicts of interest.

\section{References}

1. Institute of Medicine (US) Committee on the Health Professions Education Summit. Health professions education: a bridge to quality. In: Greiner AC, Knebel E, editors. Washington (DC): National Academies Press (US); 2003. 
2. Thibault GE. The future of health professions education: emerging trends in the United States. FASEB Bioadv. 2020;2(12):685-94.

3. Stein S. Health professions education: creating a teaching excellence module for faculty. Faculty Scholarship (PHRM). 2010:44. https://commons.pacificu.edu/work/ns/7785a539-a6554287-97a3-98dd8db54e5f. Accessed 20 Aug 2020.

4. Chen CH, Wamsley MA, Azzam A, Julian K, Irby DM, O'Sullivan PS. The health professions education pathway: preparing students, residents, and fellows to become future educators. Teach Learn Med. 2017;2:216-27.

5. Frenk J, Chen L, Bhutta ZA, Cohen J, Crisp N, Evans T, Fineberg $\mathrm{H}$, et al. Health professionals for a new century: transforming education to strengthen health systems in an interdependent world. The Lancet. 2010;376(9756):1923-58.

6. Lucas MW, Naber A. Designing interprofessional education curriculum to maximize collaborative competency. J Occup Ther Sch Early Interv. 2020;4(1):1-15. https://doi.org/10.26681/ jote.2020.040106.

7. World Health Organization. Framework for action on interprofessional education \& collaborative practice. Diana Hopkins, Editor. Health Professions Networks Nursing \& Midwifery Human Resources for Health 2010. http://www.who. int/hrh/nursing_midwifery/en/. Accessed 25 Aug 2020.

8. Olenick M, Allen LR, Smego RA Jr. Interprofessional education: a concept analysis. Adv Med Educ Pract. 2010;25(1):75-84. https:// doi.org/10.2147/AMEP.S13207.

9. Landers S, Madigan E, Leff B, et al. The future of home health care: a strategic framework for optimizing value. Home Health Care Manag Pract. 2016;28(4):262-78. https://doi. org/10.1177/1084822316666368.
10. García AA, Brown SA, Horner SD, Zuñiga J, Arheart KL. Homebased diabetes symptom self-management education for Mexican Americans with type 2 diabetes. Health Educ Res. 2015; June 30(3):454-496.https://doi.org/10.1093/her/cyv018.

11. Tucker K, Wakefield A, Boggis C, Lawson M, Roberts T, Gooch J. Learning together: clinical skills teaching for medical and nursing students. Med Educ. 2003;37(7):630-7. https://doi.org/ 10.1046/j.1365-2923.2003.01558.x.

12. Chua AZ, et al. The effectiveness of a shared conference experience in improving undergraduate medical and nursing students' attitudes towards inter-professional education in an Asian country: a before and after study. BMC Med Educ. 2015;15:1-7. https://doi.org/10.1186/s12909-015-0509-9.

13. Hamada S, Haruta J, Maeno T, Suzuki H, Takayashiki A, Baba T. Effectiveness of an Interprofessional education program using teambased learning for medical students: a randomized controlled trial. $\mathrm{J}$ Gen Fam Med. 2020;21:2-9. https://doi.org/10.1002/jgf2.284.

14. Prentice D, Engel J, Taplay K, Stobbe K. Interprofessional collaboration: the experience of nursing and medical students' interprofessional education. Glob Qual Nurs Res. 2015;2:1-9. https://doi.org/10.1177/2333393614560566.

15. Thompson S, Metcalfe $\mathrm{K}$, Boncey $\mathrm{K}$, et al. Interprofessional education in geriatric medicine: towards best practice. A controlled before-after study of medical and nursing students. BMJ Open. 2020;10(1):e018041. https://doi.org/10.1136/bmjopen-2017-018041.

Publisher's Note Springer Nature remains neutral with regard to jurisdictional claims in published maps and institutional affiliations. 